Administrative Issues Journal: Connecting Education, Practice, and Research, Summer 2016, Vol. 6, No. 1: 53-72. DOI: 10.5929/2016.6.1.2

\title{
Professionalization of Teaching in America: Two Case Studies Using Educational Research Experiences to Explore the Perceptions of Preservice Teachers/Researchers
}

\author{
James E. Gentry, Ed.D. \\ Credence Baker, Ph.D. \\ Holly Lamb, Ph.D. \\ Roberta Pate, Ph.D. \\ Tarleton State University
}

\begin{abstract}
In 2013-2015, two faculty-led educational research studies were conducted, aided by five undergraduate preservice teachers/researchers (PSTR). Faculty-researchers designed a qualitative phenomenological-inquiry based methodology to examine the PSTR perceptions regarding their respective research experiences with faculty. Triangulation of the data was sought from narrative text interview transcripts and response essays by PSTR prior to and after each respective study. Using content analysis techniques and coding, five themes emerged. PSTR reported an interest in the educational research topic and the need for positive relationships with faculty research mentors to begin and remain active with a research study. The results indicated PSTR valued learning with collaborative peers while completing their respective research studies. PSTR related self-efficacy with research skills due to their research experiences. Results indicated research experiences as a whole were professionally and personally transformative in nature. Discourse regarding research experiences to professionalize the teaching profession in America was explored.
\end{abstract}

Keywords: preservice, teachers, undergraduate, research, perceptions, professionalization

$s$ teaching in America a profession? It depends. What makes a profession a profession? One definition stands out: "A calling requiring specialized knowledge and often long and intensive academic preparation" (Merriam-Webster Dictionary.com, 2015). A profession requires specialized knowledge and academic preparation; therefore, teaching as a profession needs some consideration. To be a teacher in any state within the United States, one is required to learn specialized skills, knowledge, and content in order to provide a quality learning environment for students. To acquire such specialized knowledge and skills, a person seeking teaching as a profession must meet the required time and academic preparation standards as any other profession. Therefore, people who choose a lifestyle 
profession, like teaching, after sacrificing time and money to meet specialized requirements, should remain in the said profession for a long time.

In the teaching profession, however, this is not the reality, and research has revealed a frightening trend. According to Hentges (2012), nearly half of new teachers leave the profession within five years, representing high employee turnover rates. Hentges also determined that the loss of new teachers after a short time of employment weakens schools' ability to meet the needs of students. Teachers have cited many reasons why they leave the teaching profession early, including poor work conditions, overemphasis on testing, student misbehavior, and a perceived lack of foreseeable advancement (Harris \& Adams, 2007; Pucella, 2011; TNTP, 2012). Quality teaching and learning environments remain a critical component of the discourse concerning teaching as a profession.

Children, America's greatest resource, are valuable and deserve mentors and guides: professional teachers. Professional teachers are people who take researched best practices and apply them in various ways to accomplish goals and objectives. The American public has concerns about teaching as a profession and perceives quality teaching by quality teachers as one of the most important needs in America today (Bushaw \& Calderon, 2014). Interestingly, the American public's stance is dubious at best. Teaching as a profession is devalued by many Americans-the same Americans asking for quality (Bushaw \& Calderon, 2014; Rich, 2014; Smaller, 2015). Exacerbating the situation, policy makers calling for quality in teaching are the same people at the state level who have "reduced barriers by creating alternative routes into the profession and by sanctioning non university teacher preparation programs" (Levine, 2010, p. 21). Teaching as a profession continues to be questioned and debated in the $21^{\text {st }}$ century. One policy maker influencing the teaching profession has been the federal government. America's federal government has pushed for the professionalization of the teaching profession using several legally binding mandates tied to states' ability to obtain federal monies.

The Response to Intervention (RTI) movement was a federally initiated mandate to all public schools that began in earnest in $\mathbf{2 0 0 4}$ with the reauthorization of the Individuals with Disabilities Education Act (IDEA) (Lenski, 2011). In effect, RTI is a statement about teaching as a profession. If educators want to be in a profession, data- and research-based decisions and interventions are needed before adjusting any student's placement or learning environment (Teacher Professional Development Sourcebook, 2010). Professional teaching is more than a feeling or a guess; teaching is based on data and knowledge about a student mixed with research based pedagogical and content knowledge. The American public demands that teaching become a profession. Any teacher preparation program must consider and determine what connotes a quality teacher-as-professional.

\section{Teacher Preparation in America}

Teacher preparation as a means to prepare future teachers is under attack by policy makers, various politicians, and others (Imig, Wiseman, \& Imig, 2011). Teacher preparation and teacher roles are changing since many people outside the field have the ability to make decisions regarding teacher preparation and K-12 students' educational resources (Holland, Eckert, \& Allen, 2014). The irony found between teacher quality rhetoric and the actual policy of lawmakers is readily illustrated in how barriers 
for traditional programs or college-based teacher preparation programs have increased, while at the same time barriers for alternative teacher preparation programs have decreased (Levine, 2010). Since the A Nation at Risk report from the 1980s (Goldberg, 1983), public scrutiny concerning teaching, assessment, and quality of learning continues to be a focus of contention in America.

Teacher preparation research is limited, and little exists to connect teacher-training quality to actual classroom practice (Cochran-Smith, Cannady, McEachern, Piazza, Power, \& Ryan, 2011). Research concerning teacher preparation is needed as a means to improve and/or maintain teacher quality (Wilson, 2011). Research projects concerning the characteristics of a quality teacher are also needed today for anyone who is seriously seeking to improve American education. The retention of teachers in America is problematic and indicates a profession in crisis (Howes \& Goodman-Delahunty, 2015; Pucella, 2011; TNTP, 2012). Teacher preparation represents a salient part of the solution for improved learning outcomes and educational experiences of all students in American schools.

\section{Undergraduate Research at Higher Education Institutions}

Research is limited regarding undergraduate research experiences and opportunities; thus, empirical research into undergraduate research opportunities and experiences at undergraduate universities and colleges is warranted (Linn, Palmer, Baranger, Gerard \& Stone, 2015). Craney, McKay, Mazzeo, Morris, Prigodich, and De Groot (2009) found undergraduate students who participated in undergraduate research were more likely to graduate with a $98.5 \%$ graduation rate versus the average graduation rate of $82 \%$. Interestingly, GPA was not a factor, with a range from 2.26 to 4.0 . Craney et al. (2009) found undergraduate researchers earned more national awards with "(61\%) of the college's students receiving competitive national awards" (p. 108). Undergraduate research experiences have the potential to transform undergraduate motivation for learning research, thus generating improved self-efficacy with research methodology. Boswell (2013) found his undergraduate participants $(n=33)$ perceived knowledge of research increased when they were involved with research projects for their course. The study also found undergraduate students with a greater knowledge of research had a higher degree of interest in research and with learning how to be competent researchers. Therefore, if research knowledge and the use of research methods accompany professionalization elements for teaching (Bissonnette \& Caprino, 2014), expanding research experiences and opportunities for research at higher education institutions for undergraduates seeking teaching as a profession is an essential need, worthy of further discussion and exploration.

\section{Action Research in the Classroom}

Educational research in $\mathrm{K}-12$ classrooms is known as action research, which is a term used by educators to describe the use of research techniques and methodologies to improve teaching practices or solve instructional problems of students with diverse needs. Using data gathered from instructional experiences in order to solve instructional problems or identify needs of diverse learners is the heart of action research. Action research is a professional practice and requires an open inquiring mind, with the learning needs of students considered to be the most imperative part of instructional design (Jaruszewicz, 2006; Stringer, Christensen, \& Baldwin, 2010). K-12 education systems can be transformed 
into proactive, professional learning environments using action research as the means for all instructional decision making (Batagiannis, 2011; Good, 2009; Gravett, 2004). K-12 schools are experiencing this transformation now in various areas like science instruction and special education instruction; teachers today are finding the teacher/researcher mantle of using data for decision making fundamental to success for teaching professionals (Lebak \& Tinsley, 2010; Roach, Kurz \& Elliott, 2015). Practicing teachers and new teachers to the field need to acquire action research skills as foundational skills to be prepared for diverse classrooms today, and action research is a vital instrument for the teaching profession to garner respect as a true profession.

Unfortunately, K-12 teachers have not always connected with action research as a necessity to improve their teaching practice (Ross-Fisher, 2008). Teachers need quality professional development and experiences with action research to connect data with instructional decision making concerning student learning and progress (Clarke, 2012). Goodnough's (2011) longitudinal study followed 10 teachers for two to four years and disclosed that

Teachers reported on the many benefits of engaging in action research; enhancing their confidence in teaching science and increasing their levels of self-efficacy in relation to being able to be effective science teachers; viewing learners from a more holistic perspective and becoming more attuned to the learning needs of all students; and enhancing other aspects of their pedagogical content knowledge. (p. 83)

There are examples of action research in the literature (Camahalan \& Ruley, 2014), but this is not a widely used practice in the field (Ross-Fisher, 2008). Action research is practiced, but it is often considered an unnecessary skill for professional teachers. University-based teacher preparation programs may or may not provide opportunities for preservice teachers to practice action research techniques. Action research is a random event in most schools, but action research practices have the potential to transform teaching into a profession (Cerda, 2012). Moreover, action research experiences could validate teaching as a professional work worthy of professional recognition.

\section{Professionalizing the Teaching Profession}

Preservice teachers conducting research into learning instruction and learning environments provide positive implications for moving teaching to the realm of a profession by allowing preservice teachers to connect practice with theory (Dagenais, Lysenko, Abrami, Bernard, Ramde, \& Janosz, 2012; Lassonde, 2008; Manak \& Gregory; 2014). Professions are recognized as professional by their research and service. Teaching is a profession of service in which research has not been considered critical (Bissonnette \& Caprino, 2014). For teaching to move to a full professional status, research-based practices, both qualitative and quantitative, must dominate it (Bissonnette \& Caprino, 2014). Research-based decision making continues to be the critical missing element in the teaching profession and teacher preparation curricula (Holland, Eckert, \& Allen, 2014). Teachers using research, reflecting and observing while also contributing to the general knowledge regarding teaching and learning instruction, elevate the status of teaching as a profession. Teachers seeking to answer instructional challenges bridge the gap between researchers and practitioners (Dagenais, Lysenko, Abrami, Bernard, Ramde, \& Janosz, 2012). Therefore, 
understanding preservice teachers' perceptions concerning research is an important step if educators of teachers seek the professionalization of the teaching profession.

Requiring teacher practitioners and preservice teachers to be researchers, especially in teams, removes the barriers and transforms the us (practitioners) versus them (researchers) to we (teachersresearchers). In 2009, Marty Hittelman, President of the California Federation of Teachers, commented on reform efforts in education nationally via a USA Today editorial: "We are for research-validated changes that work, such as standards-based and common curricula that have multiple source assessments" (p. 21a). To become competitive educationally, America must seize the teacher-research professional identity since this is fast becoming the norm internationally (Goff \& Veresov, 2015; Gürsoy \& Korkmaz, 2015; Kozubovska \& Popvych, 2015; Moreno, Prudencio, \& Thomas-Ruzic 2015). In fact, Finland, a country with an exceptional education system highly regarded worldwide, has viewed the teacher-researcher identity as the professionalizing agent for the teaching profession. Teachers in Finland today complete a master's degree with strong research-based guiding curricula as a primary entry employment requirement to the teaching profession for grades past kindergarten (Toom, Kynaslahti, Krokfors, Jyrham, Byman, Sternberg, \& Kansaheh, 2010; Sahlberg, 2010; Statistics Finland, 2015). Teachers from Finland and this culture of research work in research teams to determine students' learning needs and breakthroughs (Sahlberg, 2010; Statistics Finland, 2015). For American teachers and their respective teacher preparation institutions, research ability may become the most valued required instructional design skill for making data-based, professional decisions regarding learners and the myriad of differentiated learning needs today's students manifest.

Perhaps professional American policy makers, who have decried the quality declines in teacher preparation and teaching quality, in general, could consider fashioning education policy concerning teacher education based on reviewing renowned teacher education programs internationally. American policy makers must be educated well since their decisions directly shape the level of professionalization required for employment in the teaching profession. This is of vital importance as policy makers and the American public question the value of a K-12 education from an American public school (Stoneberg, 2015). Bissonnette and Caprino's (2014) work posited one answer to quality schools and quality teaching--teachers as researchers. A preservice teacher or practicing teacher with skills and the desire to be a teacher-researcher is an appealing commodity for all American education stakeholders seeking to professionalize the teaching profession.

\section{Method}

This qualitative study used phenomenological-inquiry methodology to examine two respective case studies representing preservice teachers/researchers' experiences with educational research (Creswell, 2016; Creswell \& Plano-Clark, 2011). This study reviewed the phenomena of educational research experiences to influence professional ideas and perceptions of preservice teachers/researchers concerning the professional work of teaching and learning. Faculty-researchers sought to uncover the perceptions of undergraduate preservice teachers/researchers concerning their experiences with professor-led educational research between 2013 and 2015. Three research questions guided the study: 
1. What were the perceptions preservice teachers/researchers expressed concerning teaching and learning from engagement with educational research? Question 1 was the overarching question that guided the explorative nature of this study.

2. Will the quantitative research experience vs. the qualitative research experience produce differing perceptions between preservice teachers/researchers?

3. What lessons can be learned from preservice teachers/researchers' perceptions of their research experiences by teacher educators seeking to develop interest among undergraduate preservice teachers to participate in professional educational research experiences?

\section{Participants}

Purposeful sampling was used to identify 10 participants from a pool of 47 preservice teachers who recently completed and passed state teacher certification testing at the university. This population was chosen as potential participants since they were one semester away from clinical teaching and possible employment with school districts. Also, participants represented preservice teachers at the university who have met all testing and curricular requirements before the clinical teaching experiences began. All 47 preservice teachers maintained a 3.0 or greater grade point average, which was a requirement from the university's undergraduate research office supplying grant funds to support participants' housing and basic living needs while participating in their respective studies. This requirement was a non-issue since the grade point average of 3.0 also represented the minimum requirement for preservice teachers to remain in the university's teacher education preparation program. Five preservice teachers/researchers per study could be employed; therefore, 10 participants of the 47 preservice teachers were randomly selected and asked to participate in undergraduate faculty led educational research. For the first study, three of the five accepted. The second study retained two of the five for the faculty-led research experience. Preservice teachers declining the experience identified housing issues and time restraints as reasons for nonparticipation.

With both research projects, preservice teachers/researchers met all requirements to be accepted into the Curriculum and Instruction department's Teacher Education Program at the university and were ready to complete their clinical field teaching requirements within the next two semesters. Four participants were seeking early childhood to $6^{\text {th }}$ grade with English as a second language certification for elementary teaching. One preservice teacher/researcher who participated in the second research project sought an all-level (K-12) special education certification. The five female Caucasian preservice teachers/researchers' ages' ranged from 23 to 25 . The participants' grade point averages ranged from 3.3 to 4.0 . Their participation was voluntary; however, each participant received a small salary $(\$ 1,000)$ for their participation within the project from university grant funds used to encourage undergraduate research. Participants were representative of the demographic trends of preservice teachers in most teacher preparation programs in the United States today (Boser, 2011). Participants signed commitment contracts regarding their participation in their respective research projects with professors. 


\section{Professor-Led Research Projects}

Two research projects were initiated. The first research project, Study 1, began in 2013 and sought to validate a survey regarding practicing teachers' self-efficacy regarding technology. The second project, Study 2, began in 2014 and was an action-research project related to a single teacher's use of digital tools (e.g., green screen, IMovie, and other multimedia tools) for students to express vocabulary learning and the retelling of stories or content learned. The first research project followed a mixed design and was completed and published (Baker \& Gentry, 2014). The second research project is qualitative and is ongoing and in phase two today. Therefore, the first research project involved a more quantitative analysis and statistics; the second research project used qualitative methods and procedures. Both research projects were directed by faculty to meet professional curiosities and to gain knowledge relating to the use and perception of technology in the education field.

\section{Pre- and Post-Essay Responses}

The preservice teachers/researchers answered one essay question before participation (pre): Why are you interested in an intensive, faculty-led research experience? Once preservice teachers/researchers participation concluded, preservice teachers/researchers answered three essay related items designed to reveal their perceptions regarding their research experiences. The post response prompt and questions are listed below:

1. Describe your overall experience with this faculty led research project. Please be comprehensive...

2. What was the \#1 thing you learned by participating in this faculty led research experience? (HINT: This can be anything you believe was important.)

3. What was the greatest challenge you faced by participating in this faculty led research project?

Five peers with terminal degrees in education reviewed all pre- and post-essay responses. Pre- and postessay response questions were approved as useful and valid for this study's purpose.

\section{Pre- and Post-Unstructured Interviews}

Unbiased faculty interviewers were utilized to conduct the interviews. The interviewers were faculty who were not associated with this study. Interviews were audio recorded and transcribed. Undergraduate preservice teachers/researchers were interviewed before (pre) participation and after graduation and participation (post) using qualitative unstructured interviews (Gay, Mills, \& Airasian, 2012). The pre-interviews were guided by the prompt "Why do you want to work with this research project?" The post interviews used two questions as discussion starters:

1. How would you characterize your experiences with the research project?

2. After experiencing this educational research project, would you do it again? Explain... 
Five peers with terminal degrees in education reviewed all pre- and post-interview queries. Pre- and post-interview questions were approved as useful and valid questions designed to generate conversational style discussion.

\section{Collection Procedures for Pre- and Post-Essay Responses}

All pre-and post-essay responses were reviewed after both undergraduate research projects ended and participating undergraduate preservice teachers/researchers graduated from the university. Once preservice teachers/researchers completed both the pre-and post-questions and prompts, each participant placed their essay responses in an envelope and returned the completed artifacts to the administrative assistant in person. The administrative assistant maintained the artifacts until the preservice teachers/researchers graduated from the university. Faculty-led researchers began reviewing undergraduate preservice teachers/researchers responses beginning in the fall of 2015.

\section{Collection Procedures for Pre-\& Post- Unstructured Interviews}

Pre-and post-unstructured interviews were informal and audio recorded. The pre-interview occurred before participation in the educational research study. The post-interviews occurred after all coursework at the university was completed. Dragon Dictate software (2014) was used to assist with transcription. Also, transcription services were used to produce transcripts of the pre-and postinterviews. Undergraduate preservice teachers/researchers reviewed interview scripts and were allowed to add information for more clarification when needed.

\section{Data Analysis}

Following content analysis techniques, open coding, and axial coding procedures, pre- and post-essay responses and interview transcripts were reviewed to distinguish concepts and categories. Four faculty researchers reviewed pre-and post-narrative data separately or solo by reviewing text based data between both studies (Creswell, Hanson, Plano-Clark, \& Morales, 2007). Categories were collapsed as researchers shared analysis via peer debriefing sessions (See Figure 1). Using peer debriefing, the research team determined possible themes (Creswell, 2016; Creswell \& Miller, 2000; Spall, 1998) (See Figure 1). Krippendorff's alpha $(\alpha)$ was used to determine interrater reliability between four solo raters (Krippendorff, 1980; 2004b; 2007).

The frequency of preservice teachers/researchers' statements and percentages of those statements from the respective studies were reported. Pre-and post-statement totals and percentages by discovered theme were reported. Since all the data were text based, preservice teachers' text responses from interviews and essays were utilized as representations of the discovered themes. Also, preservice teachers' exact words were used to further provide a tangible "voice" of the preservice teachers/researchers in the study (Creswell, 2013; 2016). Peer debriefing clarified the voice of the studies' participants. Peer debriefing validated and illustrated the undergraduate preservice teachers/researchers' experiences working with qualitative- and quantitative-based research with mentor professors in a school of education at a regional state university. 
- Theme 1(T1)-personal and professional transformations

- $\quad$ Theme 2 (T2)-relationships with faculty-researchers

- $\quad$ Theme 3 (T3)-collaboration with peers

- Theme 4 (T4)-learning about technology, and

- Theme 5 (T5)-self-efficacy with research skills.

T4 represented the most statement coding support with 103 (22.01\%) statements. T1 and T5 represented similar statement support from coding with 101 (21.58\%) and 99 (21.15\%), respectively. The remaining codes, T2 and T3, represented 54 (11.54\%) and 67 (14.32\%) of the statement coding support, respectively. Four faculty-researchers' coding produced substantial internal reliability as determined by Krippendorff's $\alpha=0.885$ (Krippendorff, 2004a; Lombard, Snyder-Duch, \& Bracken, 2002).

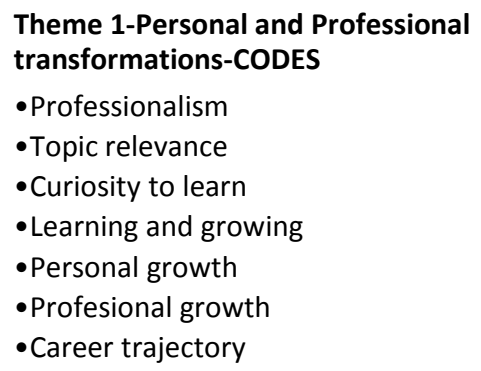

\section{Theme 2-Relationships with Faculty Researchers-CODES}

- Passionate and fun mentors

- Professors mentioned

- Relationship to professors

- Professor Influence

-Positive Relationship with professors

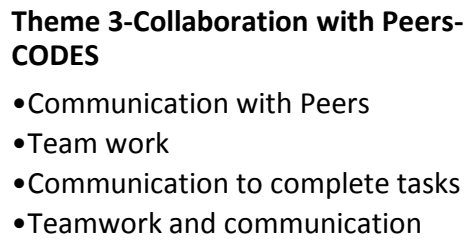

$\begin{array}{ll}\text { Theme 4-Learning about Technology- } & \text { Theme 5-Self-Efficacy in Research } \\ \text { CODES } & \text { Skills-CODES } \\ \text { - Best practices for technology } & \text { - Challenges } \\ \text { integration } & \text { - Leaning to be researcher } \\ \text { - Technology } & \text { • Research skills gained } \\ \text { - Real world use of technology for } & \bullet \text { Researching experiences related } \\ \text { teaching } & \end{array}$

Note. The codes were discovered from following a qualitative phenomenological-inquiry based methodology to examine the PSTR perceptions regarding their respective research experiences with faculty.

Figure 2. The 23 codes organized into one of five themes. Faculty-researchers organized 23 narrative text based codes into five themes through peer debriefing sessions (Creswell \& Miller, 2000).

T1 was designated as an overarching theme by faculty-researchers since this theme was the only theme to have statement overlap (17 statements, 3.63\%) with the other themes, respectively, T2(3), T3(3), $\mathrm{T} 4(3)$, and T5(8). 


\section{Qualitative: Samples of Preservice Teachers/Researchers Perceptions}

The PSTR had a voice in this project (Creswell, 2013; 2015). Their exact words provided a glimpse into the perceptions faculty-researchers discovered per theme. Through peer debriefing, PSTR and the faculty-researchers validated the codes and themes from solo codings and meetings. Although two studies with contrasting methodologies were used at different times, PSTR had many similarities.

Theme one: personal and professional transformations. T1 was determined to be an overarching theme since it overlapped (17 overlaps) with statements representing the other themes. Researchers determined $\mathrm{T} 1$ as the most crucial theme since this provided evidence of perception change or growth in seeking professional or personal goals.

- Pre-Study 1-Participant 3: I am curious about what professors do. I may become one if I can see what they do...

- Pre-Study 2- Participant 5: This experience will help me as a new teacher ...

- Post-Study 1-Participant 2: [I was] able to come to so many conclusions, and we discussed things that could be brought to administrators attention, and it will help educators become better...

- Post-Study 2-Participant 4: However, after almost completing this research, I feel very proud and accomplished.

The statements attributed to T1 codes provided examples of growth and career-mindedness. Of all the themes, T1, provided a view of the perceptions PSTR developed as they reflected on their future as professional teachers. The research experiences impacted their perceptions positively.

Theme two: relationships with faculty-researchers. There are not many axioms in teaching, but a teacher's ability to build positive relationships is a known axiom and crucial skill to be an effective classroom teacher (Corsello, Sharma, \& Jarabek, 2015; Kim \& Schallert, 2011). It is the needed skill that should be evident in elementary schools to graduate schools. PSTR recognized this need and related experiences with their professor research mentors as a reason to begin and remain with a research study.

- Pre-Study 1-Participant 2: After I saw the time and work required, I almost dropped out, but I knew learning from [professor's name omitted] was fun and could be as he says groovy.

- Post-Study 1-Participant 3: ... with [professor's name omitted] it made sense, and for the first time, I want to take a math class to learn how he did that. I need to have statistics now.

- Post-Study 2-Participant 3: I also saw [professor's name omitted] in a new way. He really is passionate about helping our profession. This research gave me a chance to see his passion in action. Also, I saw him collaborate with other professors and found the professors were as curious about the possible findings as we were. 
Theme three: collaboration with peers. PSTR valued teamwork and communication with fellow researchers when analyzing data and determining possible conclusions. Many of the findings in both studies were discovered through face-to-face and electronic (e.g., Google Documents) communications with peers. PSTR valued communication with peers when they encountered challenges or ambiguous findings with their respective studies.

- Pre-Study 2-Participant 5: I, like [peer's name omitted], believe that we are going to learn a lot from this endeavor, and I cannot wait to get the ball rolling!

- Post-Study 1-Participant 3: One other thing that I found to be a challenge during this research process was when we collaborated as a team using Google Docs, there was one point during the beginning of the process where it was hard to distinguish exactly who wrote what, when they wrote it, and if it should or shouldn't be edited. Once we all had a better understanding of how Google Docs worked, we were able to find a system that worked for us, and it became easier to distinguish what parts were written by others and when edits were made.

Theme four: learning about technology. Both studies focused on technology-related topics. Learning about the central research topic was related by PSTR in the form of specific findings. Before the respective studies commenced, PSTR expressed an interest to learn about the research topic. Also, knowledge of the topic and the possible implications for teachers were mentioned by PSTR after the research experiences for both studies.

- Pre-Study 1-Participant 1: I [will] learn from the teachers about technology... I think that will be a neat thing to see for myself.

- Pre-Study 2-Participant 4: I think the skills I will receive may provide me the knowledge to find the most effective technology for my students.

- Post-Study 1-Participant 1: For example, one of the most interesting things that I learned was teachers' perceptions of the cultural aspect of technology integration. In one article, I found that teachers perceived a certain technology approach...

- Post-Study 2-Participant 4: The number one thing I learned [from the study] is that students are more motivated and engaged when using technology.

Theme five: self-efficacy with research skills. PSTR expressed an interest in research itself and as a means to improve teaching skills. Participants viewed the research experiences and the knowledge gained from research as valuable and worth continuing in some way. Many expressed a desire to continue honing research skills. Several PSTR related perceptions of enjoyment with learning how to conduct research.

- Pre-Study 1-Participant 2: This research project is about all of this. I want to know what teacher in the classroom believe and know about themselves and using technology.

GENTRY, BAKER, LAMB, \& PATE / DOI: 10.5929/2016.6.1.2 
- Pre-Study 2-Participant 5: I believe this research will benefit me greatly, as well as many other teachers, so that we can improve students' learning.

- Post-Study 1-Participant 3: I really learned a lot during this research project. But I think the \#1 thing that I learned was that doing research like this is so important. Because by completing this research and analyzing our data, we were able to come to so many conclusions, and we discussed things that could be brought to administrators attention, and it will help educators become better... in particular with technology uses.

- Post-Study 2-Participant 4: I learned that everything has to be supported by data or other research. The first few weeks of this project all we looked at was other research that could help us in our project. I learned that this is extremely important because without other literature our research would not hold much weight.

\section{Selective Coding: Quantitative Research vs. Qualitative Research Perceptions}

Limited differences were discovered from selective coding. Similar results were cited throughout the essays and interview transcripts. In fact, faculty-researchers agreed the findings which determined the five discovered themes were adequate representations of the similarities. Only one difference was noted between quantitative Study 1 and qualitative Study 2. In the post-responses, Study 1 PSTR mentioned a need to have further education with math skills or statistics to better meet the demands of quantitative research. Statements referring to statistics as challenging or intimidating were noted by faculty-researchers as well.

- Post-Study 1-Participant 2: The statistics was not easy.... I am a words person and numbers are weird to me for explaining something. We (fellow preservice teachers/researchers)all probably need to have statistics. That was foreign to me.

- Post-Study 1-Participant 3: I know I need to learn statistics. I want to learn it.

\section{Discussion}

Undergraduate research experiences for university students seeking teacher certifications is an answer to the professionalization of the teaching profession. American policy makers, who look at Finland and other world-renowned education systems, have many examples to study, and they have the ability to professionalize teaching in each state of the United States of America using that knowledge to craft policy. The changes will require a cultural and paradigm shift from the current status quo governing most teacher preparation programs in the states. The question continues to be, "Is teaching a profession?" The United States can have a superior teacher preparation education systems by raising standards and requiring research skills as the critical tools for all certified teachers. This shift in thinking, undoubtedly, would require more time from those preparing to be teachers and more funding from each of the states and the federal government. Teaching can be a profession in America. 
The participants in these case studies were challenged with research skills ranging from literature review to conclusions based from data analysis. Professors of teacher preparation programs have the ability to entice and develop research interests of their undergraduate students by establishing positive relationships and a trusting atmosphere with their preservice teachers. Also, producing a means for preservice teachers to collaborate with peers concerning a research topic of interest is an investment that remains a worthwhile endeavor for teacher preparation programs. This was reflected in positive learning experience perceptions reported by PSTR in both studies, respectively, and these experiences have the potential to be professionally transformative in nature. New policies are needed by lawmakers, people who govern teacher preparation programs, to facilitate the professionalization of the teaching profession. The results from these case studies are a beginning.

\section{Conclusions}

Three questions guided faculty-researchers:

1. What were the perceptions preservice teachers/researchers expressed concerning teaching and learning from engagement with educational research?

2. Will the quantitative research experience versus the qualitative research experience produce differing perceptions between preservice teachers/researchers?

3. What lessons can be learned from preservice teachers/researchers' perceptions of their research experiences by teacher educators seeking to develop interest among undergraduate preservice teachers to participate in professional educational research experiences?

The first research questions sought to explore the perceptions undergraduate, preservice teachers expressed about teaching and learning concerning their experiences with educational research. The perceptions were insightful. Preservice teachers perceived their research experiences from both a professional and personal level as transformative. The international research literature regarding educational research supported such perceptions as are needed for professionalizing teaching (Gürsoy \& Korkmaz, 2015; Kozubovska \& Popvych, 2015). The preservice teachers/researchers' perceptions represented in these two case studies offered insight into the importance of professors building positive relationships with PSTR (Kim \& Schallert, 2011). Also, from PSTR-shared perceptions, faculty-researchers ascertained the positive influence of researching topics of interest to PSTR as stimulating curiosity and being motivational to continue with a research project challenge. Similar to Stephanie Boswell's (2013) results, faculty-researchers uncovered positive self-efficacy perceptions by PSTR with research skills using professor-led research experiences.

The second question asked if participating in a quantitative study versus a qualitative study produced differing perceptions regarding participation or learning with educational research experiences. Facultyresearchers found similarities, but were surprised to find few differences. The only difference noted was delivered by PSTR from Study 1, the quantitative study. Professors need to consider the PSTR background with math and statistics before initiating a quantitative based study with PSTR. Perhaps, 
PSTR could participate in research classes that reviewed statistical data procedures before and during engagement with pedagogic based research.

The third question pertained to the development of interest among preservice teachers to engage in educationally based research. The perceptions from PSTR participating in the two case studies provided some guidance for developing the interest of preservice teachers to seek research based experiences. Again, positive relationships between professors and PSTR were noted by PSTR in both case studies. PSTR trusted the professor to provide an experience that would be beneficial for them personally and professionally. PSTR need to have some interest in the research topic to engage and maintain engagement perceptions in challenging research projects. The ability of PSTR to directly perceive positive links of self-efficacy with research skills from research experiences to the entire teaching profession was the critical engagement element for continued interest with educational based research with both case studies.

Therefore, teacher preparation programs seeking to develop interest among preservice teachers to participate in research experiences need to consider the importance of trust between professors and preservice teachers as integral for the commencement of any research based curricula. Once preservice teachers begin an educationally-based research project, their continued engagement interest for any research project must be linked to positive perceptions of self-efficacy with research skills. Methods to influence positive collaborative peer interactions coupled to a pedagogical research topic found intriguing to preservice teachers must be central for the development of any research curricula designed for PSTR. Teacher preparation programs have the capability of transforming future teachers professionally and personally to become the quality teachers needed by a diverse population of students today (Gravett, 2004). This transformation of preservice teachers to perceive themselves as professionals who are capable of conducting educational research to make professional and personal decisions with classroom instruction will place the teaching profession as a recognized profession in the United States (Bushaw \& Calderon, 2014). More research experience opportunities in educational research that allow preservice teachers the ability to collaborate with peers while researching educational topics of interest constitute the invaluable transformative perception agents for the professionalization of the teaching profession in America. Teacher preparation programs need the freedom to produce confident teachers/researchers. The results derived from the narrative data, interviews and essays provide a few considerations for lawmakers. Teaching deserves professional status recognition in America.

\section{Limitations and Further Research}

The study reviewed five PSTR perceptions regarding educational research and does not represent all preservice teachers at every teacher preparation program in the United States. The results of this study cannot be generalized since purposeful sampling were utilized in order to ascertain perceptions of preservices teachers who have completed and met all required standards with state certification testing. In spite of these methodological limitations, the results of this study add to the body of knowledge pertaining to undergraduate research and preservice teacher research. This study provides curriculum designers considerations for the development of research curricula designed for preservice teachers. 
This study also adds to the discourse and research pertaining to the importance of teacher perceptions and teacher preparation in America. Although the small sample was representative of preservice teachers in the United States (Boser, 2011), it is important to note this study represents one university's findings and needs replication with differing populations and teacher preparation programs.

Further research will be needed to adequately develop educational research curricula for preservice teachers. Future research concerning teacher education preparation programs development of educational based research curricula will be beneficial. Teacher preparation programs have the means to shape the perceptions and dispositions of preservice teachers through educationally based research experiences. Policies enabling more research based experiences within teacher preparation programs are needed today to professionalize the teaching profession in America. If research skills become the norm and of value one day in most teacher preparation programs in the United States, comparative studies between teacher preparation programs within the United States and Finland, a country that values research skills in the teaching profession, would produce interesting comparative studies. These case studies are the beginning. This university and other teacher preparation programs need to continue this form of research to develop and adjust any research based curricula for preservice teachers' preparation to be professionals.

\section{References}

Baker, C., \& Gentry, J. (2014). The Targeted Open Online Course (TOOC) model. Administrative Issues Journal: Education, Practice, and Research, 4(1), 1-6.

Batagiannis, S. C. (2011). Promise and possibility for aspiring principals: An emerging leadership identity through learning to do action research. Qualitative Report, 16(5), 1304-1329.

Bissonnette, J. D., \& Caprino, K. (2014). A call to action research: Action research as an effective professional development model. Mid-Atlantic Education Review, 2(1), 12-22.

Boser, U. (2011). Teacher diversity matters: A state-by-state analysis of teachers of color. Washington, D.C.: Center for American Progress.

Boswell, S. S. (2013). Undergraduates' perceived knowledge, self-efficacy, and interest in social science research. The Journal of Effective Teaching, 12(2), 48-57.

Bushaw, W. J., \& Calderon, V. J. (2014). Americans put teacher quality on center stage: The 46th annual PDK/Gallup poll of the public's attitudes toward the public schools: Part II. Phi Delta Kappan, 96(2), 49-59. doi: 10.1177/0031721714553411

Camahalan, F. G., \& Ruley, A. G. (2014). Blended learning and teaching writing: A teacher action research project. Journal of Instructional Pedagogies, 15, 1-13. Retrieved January 01, 2016, from http://files.eric.ed.gov/fulltext/EJ1060103.pdf

Cerda, M. G. (2012, January 1). Teachers exploring partnership education and ways to transform the K-12 educational system (Doctoral dissertation). Available from ProQuest Dissertations and Theses database. (UMI No. 3509444) 
Clarke, E. J. (2012). Empowering educators through teacher research: Promoting qualitative inquiry among K-12 educators. Journal of Ethnographic \& Qualitative Research, 7(2), 64-79.

Cochran-Smith, M., Cannady, M., McEachern, K. Piazza, P., Power. C., \& Ryan, A. (2011). Teachers' education, teaching practice, and retention: A cross-genre review of recent research. Journal of Education, 191(2), 19-31.

Corsello, M., Sharma, A., \& Jarabek, A. (2015). Building assets reducing risks: Academic success for all students through positive relationships and use of real-time data. Retrieved January 19, 2016, from https://www2.ed.gov/programs/innovation/2013/spurwink.pdf

Craney, C., McKay, T., Mazzeo, A., Morris, J., Prigodich, C., \& De Groot, R. (2009). Cross-discipline perceptions of the undergraduate research experience. Journal of Higher Education, 82(1), 92-113.

Creswell, J. W. (2016). 30 essential skills for the qualitative researcher. Lincoln, NE: Sage.

Creswell, J. W. (2013). Qualitative inquiry and research design: Choosing among five approaches. Los Angeles: SAGE Publications.

Creswell, J. W., \& Plano-Clark, V. L. (2011). Designing and conducting mixed methods research. Thousand Oaks, CA: Sage.

Creswell, J. W., \& Miller, D. L. (2000). Determining validity in qualitative inquiry. Theory into Practice, 39(3), 124-130. doi: 10.1207/s15430421tip3903_2

Creswell, J. W., Hanson, W. E., Plano, V. L., \& Morales, A. (2007). Qualitative research designs: Selection and implementation. The Counseling Psychologist, 35(2), 236-264. doi: 10.1177/ 0011000006287390

Dagenais, C., Lysenko, L., Abrami, P. C., Bernard, R. M. \& Janosz, M. (2012). Use of research-based information by school practitioners and determinants of use: A review of empirical research. Evidence and Policy: A Journal of Research, Debate and Practice, 8(3), 285-309. Retrieved from http://doe.concordia.ca/cslp/cslp cms/sites/all/themes/jframe/downloads/PDF/AR2011 12 part 2.pdf

Dragon dictate for Mac [Computer software]. (2014). Burlington (Mass.): Nuance communications.

Gay, L. R., Mills, G. E., \& Airasian, P. W. (2012). Educational research: Competencies for analysis and applications. Boston: Pearson.

Goff, W., \& Veresov, N. (2015). Examining teacher-researcher collaboration through the cultural interface. Cultural Studies of Science Education, 10(3), 621-627. doi: 10.1007/s11422-015-9665-9

Goldberg, M. (1983). A Nation at Risk: The report of the National Commission on Excellence in Education. The Phi Delta Kappan, 65(1), 14-18. Retrieved from http://www.jstor.org/stable/10.2307 20386898?ref=no-x-route:cabd353db5663605e1bf29f3522fe8e7

Good, L. (2009). Using professional development to improve elementary teachers' mathematics teaching: An action research study (Doctoral dissertation). Retrieved from ProQuest Dissertations and Theses. (Order No. 3367260) 
Goodnough, K. (2011). Examining the long-term impact of collaborative action research on teacher identity and practice: The perceptions of K-12 teachers. Educational Action Research, 19(1), 73-86.

Gravett, S. (2004). Action research and transformative learning in teaching development. Educational Action Research, 12(2), 259-272

Gürsoy, E., \& Korkmaz, Ş. Ç. (2015). Teacher trainers as action researchers: Scrutinizing the reasons for student failure. Journal of Language \& Linguistics Studies, 11(2), 83-98.

Harris, D., \& Adams, S. (2007). Understanding the level and causes of teacher turnover: A comparison with other professions. Economics of Education Review, 26(3), 325-337.

Hentges, J. (2012). Why do beginning teachers leave the profession? What can be done about it? Global Education Journal , 2012 (3), 100-105.

Hittelman, M. (2009, September 20). Opposing view: We expected better. [Editorial]. The AFT Guild. Retrieved from http://aftguild.org/hot-topics/opposing-view-we-expected-better.html

Holland, J., Eckert, J., \& Allen, M. M. (2014). From preservice to teacher leadership: Meeting the future in educator preparation. Action In Teacher Education (Routledge), 36(5/6), 433-445. doi: 10.1080/01626620.2014.977738

Howes, L., \& Goodman-Delahunty, J. (2015). Teachers' career decisions: Perspectives on choosing teaching careers, and on staying or leaving. Issues in Educational Research, 25(1), 18-35.

Imig, D., Wiseman, D., \& Imig, S. (2011). Teacher education in the United States of America, 2011. Journal Of Education For Teaching, 37(4), 399-408. doi: 10.1080/02607476.2011.611006

Jaruszewicz, C. (2006). Opening windows on teaching and learning: Transformative and emancipatory learning precipitated by experimenting with visual documentation of student learning. Educational Action Research, 14(3), 357-375.

Kim, M., \& Schallert, D. L. (2011). Building caring relationships between a teacher and students in a teacher preparation program word-by-word, moment-by-moment. Teaching and Teacher Education: An International Journal of Research And Studies, 27(7), 1059-1067.

Kozubovska, I. \& Popovych, I. (2015). Training of teachers-researchers as prior consideration of professional training of pedagogues in Great Britain. Comparative Professional Pedagogy, 5(2), 4751. doi: 10.1515/rpp-2015-0039

Krippendorff, K. (1980). Content analysis: An introduction to its methodology. Beverly Hills: Sage Publications.

Krippendorff, K. (2004a). Content analysis: An introduction to its methodology ( ${ }^{\text {nd }}$ ed.). Thousand Oaks, CA: Sage.

Krippendorff, K. (2004b). Some Common Misconceptions and Recommendations. Human Communication Research, 30, 411-433.

GENTRY, BAKER, LAMB, \& PATE / DOI: 10.5929/2016.6.1.2 
Krippendorff, K. (2007). Computing Krippendorff's alpha-reliability. Annenberg School for Communication Departmental Paper 43. Retrieved from http://repository.upenn.edu/asc_papers/43/

Lassonde, C. I. (2008). Looking "Beneath the Surface": Authenticating research and inquiry for undergraduate teacher candidates. Teacher Education \& Practice, 21(1), 33-46.

Lebak, K., \& Tinsley, R. (2010). Can inquiry and reflection be contagious? Science teachers, students, and action research. Journal of Science Teacher Education, 21(8), 953-970

Lenski, S. (2011). What RTI means for content area teachers. Journal of Adolescent \& Adult Literacy, 55(4), 276-282. doi: 10.1002/JAAL.00034

Levine, A. (2010). Teacher education must respond to changes in America. Phi Delta Kappan, 91(6), 1924.

Linn, M. C., Palmer, E., Baranger, A., Gerard, E., \& Stone, E. (2015). Undergraduate research experiences: Impacts and opportunities. Science, 347(6222), 627. doi: 10.1126/science.1261757

Lombard, M., Snyder-Duch, J., \& Bracken, C. C. (2002). Content analysis in mass communication research: An assessment and reporting of intercoder reliability. Human Communication Research, 28, 587604.

Manak, J., \& Gregory, Y. (2014). Incorporating undergraduate research into teacher education: Preparing thoughtful teachers through inquiry-based learning. Council on Undergraduate Research Quarterly, 35(2), 35-38.

Price, J. M. (2010). Coding: Selective coding. Encyclopedia of Case Study Research. doi: 10.4135 /9781412957397.n56

Profession. (n.d.). Retrieved July 22, 2015, from http://www.merriam-webster.com/dictionary/profession

Rich, M. (2014, September 06). Why don't more men go into teaching? Retrieved July 23, 2015, from http://www.nytimes.com/2014/09/07/sunday-review/why-dont-more-men-go-intoteaching. html? $r=0$

Pucella, T. J. (2011). The impact of national board certification on burnout levels of educators. The Clearing House, 84, 52-58.

Roach, A. T., Kurz, A., \& Elliott, S. N. (2015). Facilitating opportunity to learn for students With disabilities with instructional feedback data. Preventing School Failure, 59(3), 168. doi: 10.1080/1045988X .2014 .901288

Ross-Fisher, R. (2008). Action research to improve teaching and learning. Kappa Delta Pi Record, 44(4), 160-164.

Sahlberg, P. (2010). The secret to Finland's success: Educating teachers. Stanford, CA: Stanford Center for Opportunity Policy in Education.

Smaller, H. (2015). The teacher disempowerment debate: historical reflections on "slender autonomy". Paedagogica Historica, 51(1/2), 136-151. doi: 10.1080/00309230.2014.997752 
Spall, S. (1998). Peer debriefing in qualitative research: Emerging operational models. Qualitative Inquiry, 4(2), 280-292. doi: 10.1177/107780049800400208

Statistics Finland (2015). Education. Retrieved September 10, 2015 from http://www.stat .fi/til/kou en.html.

Stoneberg, B. T. (2015). Real cost-benefit analysis is needed in American public education. Practical Assessment, Research \& Evaluation, 20(15-17), 1-4.

Stringer, E. T., Christensen, L. M., \& Baldwin, S. C. (2010). Integrating teaching, learning, and action research: Enhancing instruction in the K-12 classroom. Thousand Oaks, CA: Sage.

Toom, A., Kynaslahti, H., Krokfors, L. I., Jyrham, R., Byman, R., Stenberg, K., \& Kansanen, P. (2010). Experiences of a research-based approach to teacher education: Suggestions for future policies. European Journal of Education, 45(2), 331-344. doi: 10.1111/j.1465-3435.2010.01432.x

TNTP (2012). The irreplaceables: Understanding the real retention crisis in America's urban schools. Brooklyn, NY: The New Teacher Project.

Moreno, E. E. T., Prudencio, F. E., \& Thomas-Ruzic, M. (2015). Exploring authorship development among Mexican EFL teacher-researchers. Profile: Issues In Teachers' Professional Development, 17(2), 4361. doi: 10.15446/profile.v17n2.44441

What is RTI? (2010). Teacher Professional Development Sourcebook, 3(2), 12-13.

Wilson, S. (2011). How can we improve teacher quality?. Phi Delta Kappan, 93(2), 64-67.

\section{About the Authors}

James E. Gentry, Ed.D. (gentry@tarleton.edu) is an associate professor of Curriculum and Instruction at Tarleton State University. Dr. Gentry currently serves as the executive editor for The Journal for the Effective Schools Project.

Credence Baker, Ph.D. (cbaker@tarleton.edu) is an associate professor of Educational Technology and Assistant Graduate Dean at Tarleton State. She serves the editorial review board for the Journal of Online Learning and Teaching.

Holly Lamb, Ph.D. (lamb@tarleton.edu) is a professor of Curriculum and Instruction and Director of Teacher Certification at Tarleton State University. Dr. Lamb has published research projects concerning diversity at the university level.

Roberta Pate, Ph.D. (rpate@tarleton.edu), is an assistant professor of Curriculum and Instruction at Tarleton State University. She earned her Ph.D. in Education for Texas A\&M University-Corpus Christi. 